\title{
Spontaneous Drainage of Large Parapharyngeal Abscess
}

Camilla Melotti Berkembrock ${ }^{1 *}$, Laura Beatriz Firmino Werner ${ }^{1}$, Laura Roese Dacroce ${ }^{1}$, Layne Hellmann Avila Souza ${ }^{1}$, Monike Rayana Medeiros $^{1}$, Taíse de Freitas Marcelino ${ }^{2}$, Carlos Eduardo Monteiro Zappelini ${ }^{3}$

${ }^{1}$ Academics of the Medical Course of the University of Southern Santa Catarina (UNISUL), Brazil.

2 Otorhinolaryngologist and Professor of the Medical School at UNISUL, Brazil.

${ }^{3} \mathrm{PhD}$ in Otorhinolaryngology, Otorhinolaryngologist and Professor of the Medical School at UNISUL, Brazil.

*Corresponding Author: Camilla Melotti Berkembrock, Academics of the Medical Course of the University of Southern Santa Catarina (UNISUL), Brazil.

Received date: April 20, 2021; Accepted date: June 15, 2021; Published date: June 22,2021

Citation: Camilla M. Berkembrock, Laura B. F. Werner, Laura R. Dacroce, Layne H. A. Souza, Monike R. Medeiros, T. de F. Marcelino, Carlos E. M. Zappelini (2021) Spontaneous Drainage of Large Parapharyngeal Abscess, Clinical Medical Reviews and Reports. 3(6); DOI:10.31579/26908794/081

Copyright: (C) 2021, Garry F Merrill, This is an open access article distributed under the Creative Commons Attribution License, which permits unrestricted use, distribution, and reproduction in any medium, provided the original work is properly cited.

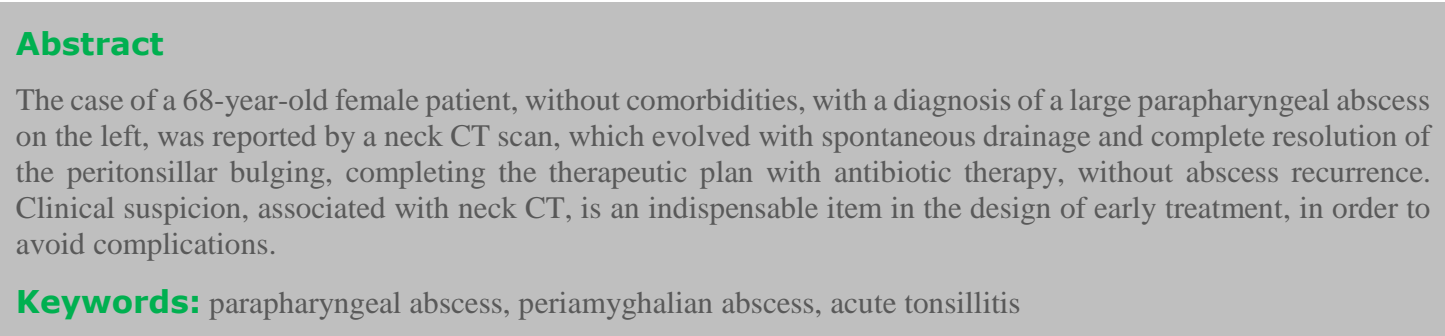

\section{Introduction}

Deep cervical abscesses are characterized by the presence of purulent material in virtual regions and fascial planes of the head and neck. Among them, parapharyngeal abscesses are located in the parapharyngeal space, which presents the base of the skull inferiorly (petrous, sphenoid bone) and the hyoid bone superiorly $[1,2]$.

Since it has extensive communication with other cervical spaces (such as the submandibular, retropharyngeal, parotid, masticatory), an assertive diagnosis and early treatment are extremely important to ensure a favorable outcome and prevent the spread of infection and progress to a complicated condition, which can have a high mortality rate $[3,4]$.

Among the etiologies, some researches point out that dental and oropharyngeal infections account for more than $90 \%$ of cases $[4,5]$. Other causes include foreign bodies, trauma or cervical surgery and immunosuppression (such as HIV and diabetes) [4, 5]. Regarding epidemiology, abscesses affect men and women equally, in different age groups [5].

The symptoms vary according to the region and the extension of the affected area, being frequent symptoms: fever, odynophagia, trismus, cervical edema, nausea and lymphadenopathy, and, in more exacerbated cases, dyspnea, airway obstruction, cervical necrotizidwng fasciitis, empyema and thrombosis of the jugular vein [6].

For presenting a non-specific clinical condition, imaging exams, such as computed tomography (CT), are useful options to make the diagnosis and point out the lesion's location and extent with greater precision, as well as help the therapeutic decision, which is used from antibiotic therapy to drainage to early surgical intervention $[7,8]$.

The objective of this study is to present a case of large parapharyngeal abscess, approaching the methods used in diagnosis and treatment, which presented a favorable outcome.

\section{Case report}

A 68-year-old woman complaining of persistent odynophagia, mainly on the left, for three weeks. She denies fever or trismus. Denied comorbidities. During the period, she used amoxicillin in combination with clavulanate and symptomatic medications. On physical examination, she presents pain on palpation at level $1 \mathrm{~b}$ on the left and in oroscopy voluminous bulging of the left peritonsillar region, without trismus.

A computed tomography scan of the neck was done, showing the presence of a collection of irregular contours and defined limits, occupying the left parapharyngeal space, extending to the sublingual and submandibular homolateral space, with a little medial displacement of the left palatal tonsil, with luminal reduction of the oropharynx, defined limits and measured $2.9 \times 2.5,3.2$ (figure 1-A, 1-B, 1-C).

After performing the exam, the patient returns to surgical drainage orientation, however, there was already a drainage orifice with complete reduction of the peritonsillar bulging to the left (figure 1-D). She is still being monitored and using acetylcefuroxime, and after 10 days there has been no recurrence of the abscess. 


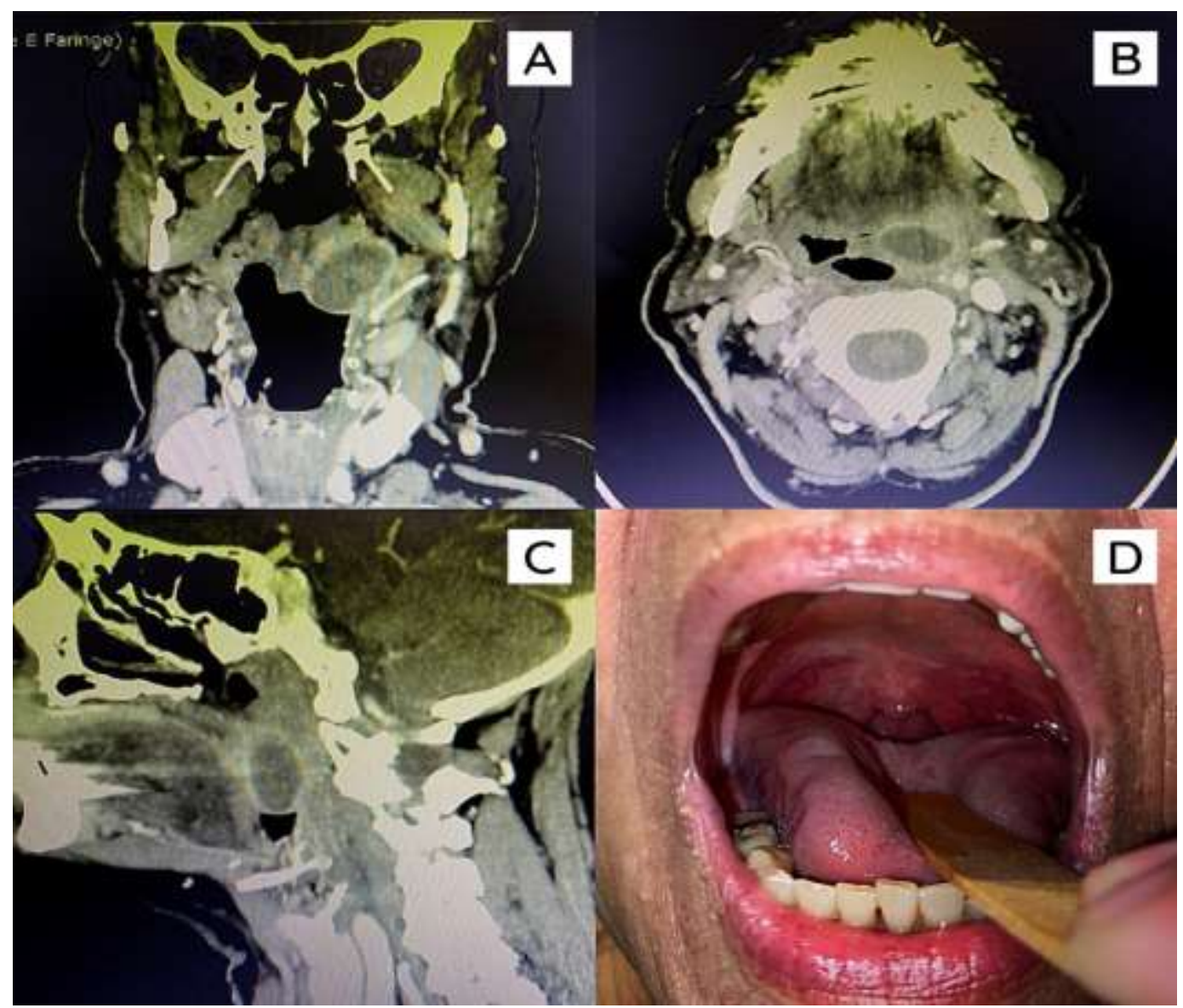

Figure 1: Computed tomography of the neck showing collection in space parapharyngeal (A: coronal section, B: axial section, C: sagittal section). D: oroscopy after spontaneous abscess drainage.

\section{Discussion}

Deep cervical abscesses are diseases of high importance due to their frequency and possible complications, and although the incidence has significantly decreased with the use of antibiotics, this condition is still associated with high morbidity and mortality [1]. The anatomical knowledge of the cervical fasciae and the deep cervical spaces defined by it is fundamental for an adequate therapeutic strategy in addition to a good understanding of complications [9].

These infections affect both sexes and have no preference for age [1]. In the case described, the studied patient did not have identifiable risk factors or associated comorbidities, a fact corroborated by a prospective study on deep periamigdalian and cervical infections, where most people with this condition also did not have comorbidities [10]. However, some risk factors are associated with the disease and should be investigated, such as infections, trauma or previous cervical surgery, foreign bodies, immunosuppression and some comorbidities, such as diabetes mellitus, tumors, HIV, among others [11].

According to the literature, odontogenic causes characterize the main primary infectious focus in adults, while in the pediatric population, ear infections or upper airway infections predominate [12]. However, a significant number of cases do not have an identifiable starting point, with reports that vary up to $50 \%$ according to some studies and in accordance with the case described $[13,14]$, because the source of primary infection in some cases may precede the condition for weeks [1].

Contrast computed tomography is the exam of choice for the diagnosis of cervical abscesses [15]. However, nuclear magnetic resonance, ultrasound and some laboratory tests, such as blood count, erythrocyte sedimentation rate, C-reactive protein, and culture for bacterial growth can also help in the diagnosis and in the choice of an appropriate therapeutic strategy [16].

The clinical manifestations are varied and depend on the affected cervical area ${ }^{13}$, as already mentioned in the Introduction. In the reported case, the prevalent symptom was odynophagia, without the presence of fever or trismus, corroborating with some other studies where odynophagia was also found as the main symptom [10, 14].

Treatment is based on antibiotic therapy, maintenance of airway permeability and often there is a need for surgical drainage [17]. It is indicated in cases of extensive cervical abscesses with suspected complications, when there is no improvement after 24 to 48 hours of clinical treatment, and depending on the patient's general condition ${ }^{9}$. The antibiotic therapy used in the case initially was amoxicillin with clavulanate, which is also described as the first line of treatment in most studies $[1,18]$.

In addition, the parapharyngeal space, where the infection is located, has communication with several cervical spaces (submandibular, retropharyngeal, parotid, masticatory), and is important in the spread of infections [9]. Among the main complications are: airway obstruction, aspiration pneumonitis or lung abscess secondary to rupture of peritonsillar abscess, extension of infection in the deep tissues of the neck or upper mediastinum, life-threatening hemorrhage secondary to erosion or septic necrosis in the carotid sheath in addition to post-streptococcal sequels, such as glomerulonephritis and rheumatic fever [19].

In the case described there was spontaneous drainage of the abscess, and 
surgical drainage was not necessary. A study that analyzed factors that affect the length of hospital stay and the presence of complications in cervical abscesses showed a spontaneous drainage rate in $25.6 \%$ of cases. However, spontaneous abscess drainage was significantly associated with a longer hospital stay [13].

\section{Conclusion}

The present study reports the case of a 68 -year-old female patient, without comorbidities, complaining of persistent odynophagia, presenting peritonsillar bulging to the left, despite adequate antibiotic therapy. A neck CT scan was performed, which proved the presence of a large collection taking up space for the left pharyngeal, with indication for surgical drainage.

However, the surgical procedure was not necessary, since there was spontaneous drainage of the abscess, with complete resolution of the peritonsillar bulging, and its therapeutic plan was finalized through clinical monitoring and use of acetylcefuroxime, allowing a favorable outcome without abscess recurrence. The clinical suspicion, associated with the complementary exam, are indispensable items in the design of the early treatment, in order to avoid complications that can be associated with high morbidity and mortality.

\section{References}

1. Brito TP, Hazboun IM, Fernandes FL, Bento LR, Zappelini CEM, Chone CT et al. (2017) Deep neck abscesses: study of 101 cases. Braz. j. otorhinolaryngol. 83(3): 341-348.

2. Sakagushi M, Sato S, Ishiyama T, Katsuno S, Tagushi K. (1997) Characterization and management of deep neck infection. J Oral Maxillofac Surg. 26:131-4.

3. Motahari SJ, Poormoosa R, Nikkhah M, Bahari M, Shirazi SAM, Khavarinejad OF. (2015) Treatment and prognosis of deep neck infections. Indian J Otolaryngol Head Neck Surg. 67:9-105

4. Oliver E; Gillespie M. (2010) Deep neck Space Infections In: Flint P (Eds.) Cummings Otolaryngology, Head and Neck Surgery, Philadelphia, Mosby-Elsevier. pp201-209

5. Soares MT, Costa E, Durão C, Henriques P, Veiga VG. (2015) Infecções cervicais profundas, casuística do serviço de otorrinolaringologia do Hospital Prof. Doutor Fernando Fonseca. Rev Port Otorrinol Cir Cervico Fac. 53(3): 161- 5

6. Li RM, Kiemeney M. (2019) Infections of the Neck. Emerg. Med. Clin. N. Am. 37(1):95-107
7. Gorjón P, Pérez P, Martin A, Dios J. et al. (2012) Deep Neck Infection: Review of 286 Cases. Acta Otorrinolaringol Esp. 63(1):31-41

8. Buckley J, Harris A.; Addams WJ. (2019) Ten years of deep neck space abscesses. J Laryngol Otol. 133(4):324-8.

9. Köbe BM, Alves LS, Köbe LM, Steffen N. (2014) Abscessos cervicais. Acta méd (Porto Alegre). 1-19.

10. Estêvão, R., Caselhos, S., Veloso Teles, R., Castro e Sousa, A., Henriques, V., Matos, C., \& Fernandes, F. (2014) Infecções periamigdalinas e cervicais profundas - Estudo prospectivo. Revista Portuguesa De Otorrinolaringologia E Cirurgia De Cabeça E Pescoço, 52(3), 133-138.

11. Hasegawa J, Hidaka H, Tateda M, Kudo T, Sagai S, Miyazaki M, et al. (2011) An analysis of clinical risk factors of deep neck infection. Auris Nasus Larynx. 38:101.

12. OZONO, Y.; et al. (2019) Rupture of Internal carotid artery pseudoaneurysm in the sphenoid sinus as a complication of deep neck space infection. The Journal of Medical Investigation, 66, n1, 188-189.

13. Ferreira, F., São Pedro, R., Proença, V., \& Antunes, L. (2021) Abcessos cervicais: Fatores que afetam o tempo de internamento e a presença decomplicações. Revista Portuguesa De Otorrinolaringologia E Cirurgia De Cabeça E Pescoço, 59(1), 31-39.

14. Abdel-Haq NM, Harahsheh A, Asmar BL. (2006) Retropharyngeal abscess in children: the emerging role of group A beta hemolytic streptococcus. South Med J. 99:927.

15. Chow AW. (2013) Deep neck space infection. In: UpToDate. Online.

16. BAN, M.J.; et al. (2018) A clinical prediction score to determine surgical drainage of deep neck infection: A retrospective case control study. International Journal of Surgery, 52, 131-135.

17. Priyamvada S, Motwani G. (2019) A Study on Deep Neck Space Infections. Indian J Otolaryngol Head Neck Surg. 71(Suppl 1):912-7. doi 10.1007/s12070- 019-01583-4

18. Rzepakowska A, Rytel A, Krawczyk P, et al. (2019) The Factors Contributing to Efficiency in Surgical Management of Purulent Infections of Deep Neck Spaces. Ear, Nose \& Throat Journal.

19. Tagliareni JM, Clarkson EI. (2012) Tonsillitis, Peritonsillar and Lateral Pharyngeal Abscesses. Oral Maxillofac Surg Clin North Am. 24(2):197-204.
This work is licensed under Creative Commons Attribution 4.0 License

To Submit Your Article Click Here: Submit Manuscript

DOI: $10.31579 / 2690-8794 / 081$
Ready to submit your research? Choose Auctores and benefit from:

* fast, convenient online submission

* rigorous peer review by experienced research in your field

* rapid publication on acceptance

* authors retain copyrights

* unique DOI for all articles

* immediate, unrestricted online access

At Auctores, research is always in progress.

Learn more www.auctoresonline.org/journals/clinical-medical-reviewsand-reports- 